\title{
INCREASING CONCENTRATION OF DEICING SALT IN SOILS IN THE BAVARIAN FOREST NATIONAL PARK
}

\section{ZDENKA KŘENOVÁ1,2,*, VLADIMÍR ZÝVAL ${ }^{3}$, VLADIMÍR ZÝVAL JR. ${ }^{3}$, and ZDEŇKA CHOCHOLOUŠKOVÁ ${ }^{4}$}

\author{
${ }^{1}$ Global Change Research Centre AS CR, v.v.i., Bělidla 4a, CZ-60200 Brno, Czech Republic \\ ${ }^{2}$ Charles University, Faculty of Sciences, Benátská 2, CZ-12900 Prague, Czech Republic \\ ${ }^{3}$ GeoVision s.r.o., Brojova 2113/16, 32600 Plzeň 2 - Slovany, Czech Republic \\ ${ }^{4}$ Department of Biology, Faculty of Education, University of West Bohemia in Plzeň, Univerzitní 8, 30614 Plzeň, Czech Republic \\ * Corresponding author: zd.krenova@gmail.com
}

\begin{abstract}
The negative effects of applying deicing salts to ecosystems are well documented for many countries. Most chemical transport from roads occurs in stormwater runoff through or over soil. Runoff pollutants alter soil chemistry, may be absorbed by plants and affect stream ecosystems, where they are dispersed and diluted over considerable distances. There was little detailed knowledge of the effects of deicing salts on ecosystems in the Bavarian Forest NP until 2011, when nine permanent sites were established along the main road in the eastern part of the NP. Soil samples were collected from four of these permanent sites in 2012, 2015 and 2018 and analysed by a certified laboratory. The results of soil chemical analysis were used to compare sites and samples from years 2012, 2015 and 2018. Our research confirmed the increasing concentrations of $\mathrm{Na}^{+}$and $\mathrm{Cl}^{-}$ions in ecosystems in the Bavarian Forest NP. The highest concentrations of $\mathrm{Na}^{+}$and $\mathrm{Cl}^{-}$ions were recorded in samples from sites \# 4 and 5, which are located only several meters from the bank of the Grosse Ohe River. These concentrations were more than ten times higher than in samples from sites where deicing salt was not used. Amphibians, water insects and other extremely sensitive species and habitats occur in this part of the Bavarian Forest NP and are probably suffering from increasing salinity of their habitats. More research focusing on a better understanding of the spread of deicing salt in the ecosystem together with improving road maintenance technologies are need in order to improve the situation.
\end{abstract}

Keywords: ecosystem contamination; national park; road salting; soil chemistry

\section{Introduction}

Roads are a widespread and increasing feature of most landscapes. There are many scientific publications that support the general conclusion that roads have negative effects on the biotic integrity of both terrestrial and aquatic ecosystems (e.g. Trombulack and Frissell 1999). Roads of all kinds have several general effects: mortality from road construction, mortality from collision with vehicles, modification of animal behaviour, alteration of the physical environment including habitat fragmentation, alteration of the chemical environment, spread of exotics and increase in use of areas by humans (van der Ree et al. 2015).

The negative effects of applying deicing salts to ecosystems are well known and documented for many countries, both in urban and natural areas (Findlay and Kelly 2011). Most chemical transport from roads occurs in stormwater runoff through or over soil (Forman and Alexander 1998). Runoff pollutants alter soil chemistry, may be absorbed by plants and affect stream ecosystems, where they are diluted and dispersed over considerable distances (Gilson et al. 1994; Yousef et al. 1985). Deicing salt and heavy metals are the two main categories of pollutants in road runoff. The primary deicing agent, $\mathrm{NaCl}$, corrodes vehicles and bridges, contaminates drinking water supplies and is toxic to many species of plants, fish and other aquatic organisms. Sometimes calcium magnesium acetate (CMA) is used as it is a more effective deicer, less corrosive, less mobile in soil, biodegradable and less toxic to aquatic organisms (National Research Council 1991; Ostendorf et al. 1993; Forman and Alexander 1998). Also, $\mathrm{CaCl}$ used to decrease dust may inhibit amphibian movement (eMaynadier and Hunter 1995). Airborne $\mathrm{NaCl}$ from snow ploughing of roads may also cause injury to the leaves of trees up to $120 \mathrm{~m}$ from a road, especially downwind and downslope (Hofstra and Hall 1971; Czerniawska-Kusza 2004; personal observation too).

Sodium accumulation in soils, mainly within $5 \mathrm{~m}$ of a road, alters soil structure, which affects plant growth and plant species composition. Deicing agents tend to increase the mobility of chemical elements in soil, such as heavy metals (by $\mathrm{NaCl}$ ) and $\mathrm{Na}, \mathrm{Cl}, \mathrm{Ca}$ and $\mathrm{Mg}$ (by CMA) (Amrhein et al. 1992; Bäckström et al. 2004). This process facilitates contamination of groundwater, aquifers and streams (Cunningham et al 2007). Because of dilution, the chemical effects of road runoff on surface water ecosystems may be primarily confined to small streams, particularly those adjacent to roads (Fennessey 1989).

In cold regions, deicing salts applied to roads are a major contributor to local and regional contamination, while salts from water softeners and septic systems are less important. There is emerging evidence that $\mathrm{NaCl}$, the most often used deicing salt, contrary to what was previously thought is not transported rapidly through the soil and groundwater (Mason et al. 1999; Bryson and Barker 2002; Godwin et al. 2003). The retention via 
several mechanisms means that the flushing-out of winter-applied salts does not occur, and high concentrations may be present during summer when biological activity is high. This can affect the living conditions of water organisms, especially their most sensitive developmental stages. Several studies document the negative cumulative effects on amphibians breeding in vernal pools near roads (Karraker et al. 2008). Denoel et al. 2010 report no effects on mortality or growth of amphibians but a reduction in the speed of movement of tadpoles at sites where there is a high concentration of salt. High concentrations of salt affect competition and predation and also cause significant changes in plant (i.e. Angold 1997; Richburg et al. 2001; Wrobel et al. 2006) and soil invertebrate communities (Rusek and Rusek 1999).

In some countries, for example the Czech Republic, the application of deicing salts to roads in protected areas is prohibited by law. In the Šumava National Park, the nearest trans-boundary partner of the Bavarian Forest NP, there are special exceptions for several main roads, where deicing salts are applied but only when particular conditions prevail and are monitored (Zýval et al. 2015, 2018). The monitoring of the effects of deicing salt on ecosystems in the Šumava NP was started in 2003, but the first monitoring was carried out already in the 1990s.

Deicing salt is regularly applied along the "Nationalparkstrasse" road, the main road in the eastern part of the Bavarian Forest NP, however nothing was known about the effects of this until 2011 when the first monitoring was started (Křenová et al. 2012). A monitoring program was prepared (Křenová 2011) and a standard monitoring design implemented (Zýval et al. 2015). Together with the monitoring of vegetation (i.e. phytoindication), soil structure and soil chemistry were also investigated at permanent sites along the "Nationalparkstrasse" road.

In this paper, we present results of soil chemical analysis, compare data collected in 2012, 2015 and 2018, and discuss trends in contamination of ecosystems in the NP.

\section{Methodology}

\section{Study area}

The Bavarian Forest National Park (24,235 ha, established 1970) is located in the German part of the Bohemian Forest and is contiguous with similar forests in the Czech Republic, where the Šumava National Park is located. These two national parks share a forest landscape, which is one of the largest in Central Europe and covers the highest ridges of the low mountain range that form the watershed between the Danube and Elbe catchment areas. About $98 \%$ of the Bavarian Forest NP is covered by forest (Elling et al. 1987) and peat bogs are the second most important habitat in this area.

This region is characterized by montane and high montane areas within a vertical range of approximately
$800 \mathrm{~m}$ (from $650 \mathrm{~m}$ to $1420 \mathrm{~m}$ a. s. 1.). At a larger scale, the Bavarian Forest is in the temperate zone and subject to both Atlantic and continental influences. The total annual precipitation is between 1200 and $1800 \mathrm{~mm}$ depending on altitude. Annual mean air temperature varies between $5.1^{\circ} \mathrm{C}$ in the valleys, $5.8^{\circ} \mathrm{C}$ on hillsides and $3.8^{\circ} \mathrm{C}$ in the high montane zones (Noack 1979; Bässler 2004). Geologically, the Bavarian Forest is on the southwestern part of the Bohemian Massif (Variscian basement), which consists mainly of granite and gneiss. Consequently, soils are acidic, sandy and loamy (particularly brown earths and podsols) and partly covered with rocks. At all altitudes, but especially in the valleys, there is characteristically a persistent or intermittent water table in both mineral and organic soils (Bässler et al. 2009).

"Nationalparkstrasse", a main road in the eastern part of the Bavarian Forest NP, was constructed soon after opening the Bavarian Forest NP in 1970s. This road runs through the south-eastern edge of the Bavarian Forest $\mathrm{NP}$ and connects the main visitor facilities, including the main visitor centre and canopy trail. The road is open all year and frequently used by private cars and 'Igle Busses', i.e. green buses organized by the Bavarian Forest NP Authority. Local people also often use this road. It is the only usable road for some of them for travelling to their jobs or schools. The road is maintained by the Landratsamt Freyung-Grafenau office, which confirmed applying deicing salt usually from late November to April. The frequency and amount of deicing salt depends on climatic conditions and varies from $10 \mathrm{~g} / \mathrm{m}^{2}$ to $40 \mathrm{~g} / \mathrm{m}^{2}$. They said that only rock salt $\mathrm{NaCl}$ is used for deicing roads in the Bavarian Forest NP.

A monitoring of the effect of deicing salt along this road was agreed with the Bavarian Forest NP Authority

Table 1 The study sites and their geographical characteristics. The sites from which soil samples were collected are in bold.

\begin{tabular}{|l|l|l|c|c|}
\hline $\begin{array}{l}\text { Site } \\
\#\end{array}$ & Name & GPS & Altitude m a.s.I. & $\begin{array}{c}\text { Salt } \\
+/-\end{array}$ \\
\hline 1 & Mauth - main road & $\begin{array}{l}\text { N48 53.118 } \\
\text { E13 34.522 }\end{array}$ & 772 & + \\
\hline 2 & Mauth - control & $\begin{array}{l}\text { N48 53.218 } \\
\text { E13 34.551 }\end{array}$ & 773 & - \\
\hline $\mathbf{3}$ & Racheldiensthütte & $\begin{array}{l}\text { N48 55.401 } \\
\text { E13 24.644 }\end{array}$ & $\mathbf{7 7 3}$ & - \\
\hline $\mathbf{4}$ & Grosse Ohe - west & $\begin{array}{l}\text { N48 55.416 } \\
\text { E13 24.862 }\end{array}$ & $\mathbf{7 6 5}$ & + \\
\hline $\mathbf{5}$ & Grosse Ohe - east & $\begin{array}{l}\text { N48 55.406 } \\
\text { E13 24.817 }\end{array}$ & $\mathbf{7 6 4}$ & + \\
\hline 6 & Waldhäuser & $\begin{array}{l}\text { N48 56.237 } \\
\text { E13 27.288 }\end{array}$ & 847 & + \\
\hline 7 & Grosse Filz & $\begin{array}{l}\text { N48 55.338 } \\
\text { E13 25.210 }\end{array}$ & 777 & + \\
\hline $\mathbf{8}$ & Guglöd & $\begin{array}{l}\text { N48 55.388 } \\
\text { E13 25.106 }\end{array}$ & $\mathbf{7 6 9}$ & + \\
\hline 9 & Atlschönau & $\begin{array}{l}\text { N48 54.664 } \\
\text { E13 27.977 }\end{array}$ & 748 & + \\
\hline
\end{tabular}


and the first survey of the study area was done during the summer of 2011. "Nationalparkstrasse" and two roads running tangentially to this road to Waldhäuser and Racheldienesthütte were included in this project. The road to Waldhäuser is also treated with deicing salt, while the road to Racheldienesthütte is closed for public transport and only infrequently treated.

\section{Data collection and analyses}

Nine permanent sites were established in the study area, seven of which were located along roads where deicing salts were regularly applied (the main road $\mathrm{Na}$ tionalparkstrasse and the road to Waldhäuser). Two of the study sites were along roads that were not salted and they were used as control sites. All sites were provided

Table 2 Soil profiles and their characteristics at sites \# 3, 4, 5 and 7. Sample 1 was located five meters and sample 2 ten meters from the edge of the road. Samples (in bold) were collected in periodically flooded depressions along the Grosse Ohe River at sites \# 4 and 5.

\begin{tabular}{|c|c|c|c|}
\hline & Sample & Depth (m) & Soil characteristics \\
\hline \multirow[t]{6}{*}{ Site \# 3} & 1 & $0-0.05$ & organogenic soil \\
\hline & & $0.05-0.3$ & organogenic soil with lower proportion of silk \\
\hline & & $>0.3$ & organogenic soil with lower proportion of silk and sand \\
\hline & 2 & $0-0.05$ & organogenic soil \\
\hline & & $0.05-0.3$ & organogenic soil with lower proportion of silk \\
\hline & & $>0.3$ & organogenic soil with lower proportion of silk and sand \\
\hline \multirow[t]{7}{*}{ Site \# 4} & 1 & $0-0.05$ & sandy soil, grey-black, humic \\
\hline & & $0.05-0.3$ & loamy sand soil, grey, locally red spots, lower more clay - flooded alluvium \\
\hline & & $>0.3$ & grey-black clay \\
\hline & 2 & $0-0.05$ & sandy soil, grey-black, humic \\
\hline & & $0.05-0.3$ & shallow grey sandy clay, \\
\hline & 3 & $0-0.05$ & sandy soil, grey-black, humic, periodically flooded local depression \\
\hline & & $0.05-0.3$ & shallow grey sandy clay, \\
\hline \multirow[t]{6}{*}{ Site \# 5} & 1 & $0-0.3$ & grey-green sandy soil, red-rusty glay; with paragneiss debris - probably periodically flooded alluvium \\
\hline & & $>0.3$ & gravel \& stones \\
\hline & 2 & $0-0.2$ & sandy soil, black to grey-black, humic \\
\hline & & $0.2-0.3$ & grey stony sand - periodically flooded alluvium \& buried humic horizon \\
\hline & 3 & $0-0.3$ & grey-green sandy soil, red-rusty glay; with paragneiss debris - periodically flooded depression \\
\hline & & $>0.3$ & gravel \& stones \\
\hline \multirow[t]{5}{*}{ Site \# 8} & 1 & $0-0.05$ & grey-brown clay, slightly humic, partly decomposed litter \\
\hline & & $0.05-0.4$ & strongly sandy soil, brown, with paragneiss debris \\
\hline & & $>0.5$ & permanently waterlogged \\
\hline & 2 & $0-0.05$ & grey-brown clay, slightly humic, partly decomposed litter \\
\hline & & $0.05-0.4$ & strongly sandy soil, red-brown, paragneiss debris \\
\hline
\end{tabular}

Table 3 Descriptive statistics of 60 soil samples collected in years 2012, 2015 and 2018.

\begin{tabular}{|l|l|c|c|c|c|c|}
\hline Variable & \multicolumn{1}{|c|}{ Extraction } & Valid N & Mean & Minimum & Maximum & Std. Dev. \\
\hline $\mathrm{Ca}^{2+}[\mathrm{mg} / \mathrm{kg}]$ & Moehlich II & 60 & 957.64 & 0.40 & 5180.00 & 1316.21 \\
\hline $\mathrm{K}^{+}[\mathrm{mg} / \mathrm{kg}]$ & Moehlich II & 60 & 112.95 & 11.90 & 312.50 & 68.01 \\
\hline $\mathrm{Mg}^{2+}[\mathrm{mg} / \mathrm{kg}]$ & Moehlich II & 60 & 227.56 & 3.50 & 1950.00 & 414.37 \\
\hline $\mathrm{Na}^{+}[\mathrm{mg} / \mathrm{kg}]$ & Moehlich II & 60 & 281.79 & 0.40 & 1280.00 & 300.78 \\
\hline $\mathrm{Na}^{+}[\mathrm{mg} / \mathrm{l}]$ & water & 60 & 12.48 & 1.00 & 60.30 & 13.89 \\
\hline $\mathrm{Cl}^{-}[\mathrm{mg} / \mathrm{l}]$ & water & 60 & 14.21 & 0.90 & 141.00 & 22.96 \\
\hline $\mathrm{Conductivity}[\mathrm{mS} / \mathrm{m}]$ & & 60 & 10.00 & 1.67 & 58.50 & 10.04 \\
\hline $\mathrm{pH}($ water$)$ & & 60 & 6.25 & 4.66 & 7.90 & 0.69 \\
\hline $\mathrm{pH}(\mathrm{KCl})$ & & 60 & 3.88 & 3.00 & 6.50 & 0.54 \\
\hline
\end{tabular}


with blue permanent markers, had their GPS positions recorded (Table 1) and photographed.

Two five-meters long transects were established at each site in August 2011 in order to identify the plants occurring there. The species occurrences and their salt-tolerance were repeatedly studied (Křenová et al. 2012; Zýval et al. 2015).

Soil conditions were recorded at all these sites at distances of 5 and 10 meters from the road edge (Table 2). Samples of soil were collected at distances of 5 and 10 meters from the road edge at four sites (Site \# 3, 4, 5 and 8) in 2012, 2015 and 2018. The soil samples were collected from the upper $(0 \mathrm{~m}$ to $-0.10 \mathrm{~m})$ and lower soil horizons $(>-0.10 \mathrm{~m})$ at four points and then samples from each soil horizon mixed for each site.

Each soil sample was marked with a specific code. The first digit was the site number, the second digit was the distance from the edge of the road $(1=5 \mathrm{~m}, 2=10 \mathrm{~m})$ and the third digit was the horizon of soil sampled ( $1=$ upper $10 \mathrm{~cm}, 2=$ deeper than $10 \mathrm{~cm}$ ).

In 2012, 2015 and 2018, the mixed soil samples for each site were analysed by a certified laboratory in Klatovy (LABTECH Brno s.r.o - Laboratory Klatovy) and the following parameters measured:

- after water extraction: $\mathrm{pH}_{\mathrm{H} 20}, \mathrm{Na}^{+}, \mathrm{Cl}^{-}$, conductivity;

- Moehlich II: $\mathrm{Ca}^{2+}, \mathrm{Mg}^{2+}, \mathrm{K}^{+}, \mathrm{Na}^{+}$;

$-\mathrm{pH}_{\mathrm{KCl}}$.
We used the analysis of variation in STATISTICA 12 (Anonymous 2012) to compare the study sites and determine the effect of distance from the edge of the road and soil sample horizon on the concentration of $\mathrm{Na}^{+}$and $\mathrm{Cl}^{-}$ ions. We also tested for trends over time and compared samples from 2012, 2015 and 2018 in Repeated Measurement in Split-plot ANOVA in STATISTICA 12. Logarithmic transformation $\log (\mathrm{x}+1)$ was used to standardize the data.

\section{Results}

A total of sixty samples collected in 2012, 2015 and 2018 , were analysed. A set of twenty samples were collected and sent for laboratory analyses each year ( $\mathrm{Ta}-$ ble 3).

The sites studied differed significantly in all variables analysed, except $\mathrm{pH}_{\mathrm{H} 20}$ (ANOVA, $\mathrm{p}<0.05$; Fig. 1). Site \# 3 had the highest concentrations of cations $\left(\mathrm{Ca}^{2+}\right.$, $\left.\mathrm{Mg}^{2+}, \mathrm{K}^{+}\right)$and the lowest ions from deicing salt $\left(\mathrm{Na}^{+}\right.$, $\left.\mathrm{Cl}^{-}\right)$. The highest concentrations of the salt ions $\left(\mathrm{Na}^{+}\right.$, $\mathrm{Cl}^{-}$) were recorded in samples from site \# 4 and only slightly lower concentrations in samples from site \# 5 . The lowest concentrations of cations $\left(\mathrm{Ca}^{2+}, \mathrm{Mg}^{2+}, \mathrm{K}^{+}\right)$ and low concentrations of the salt ions $\left(\mathrm{Na}^{+}, \mathrm{Cl}^{-}\right)$were recorded in the samples from site \# 8 .

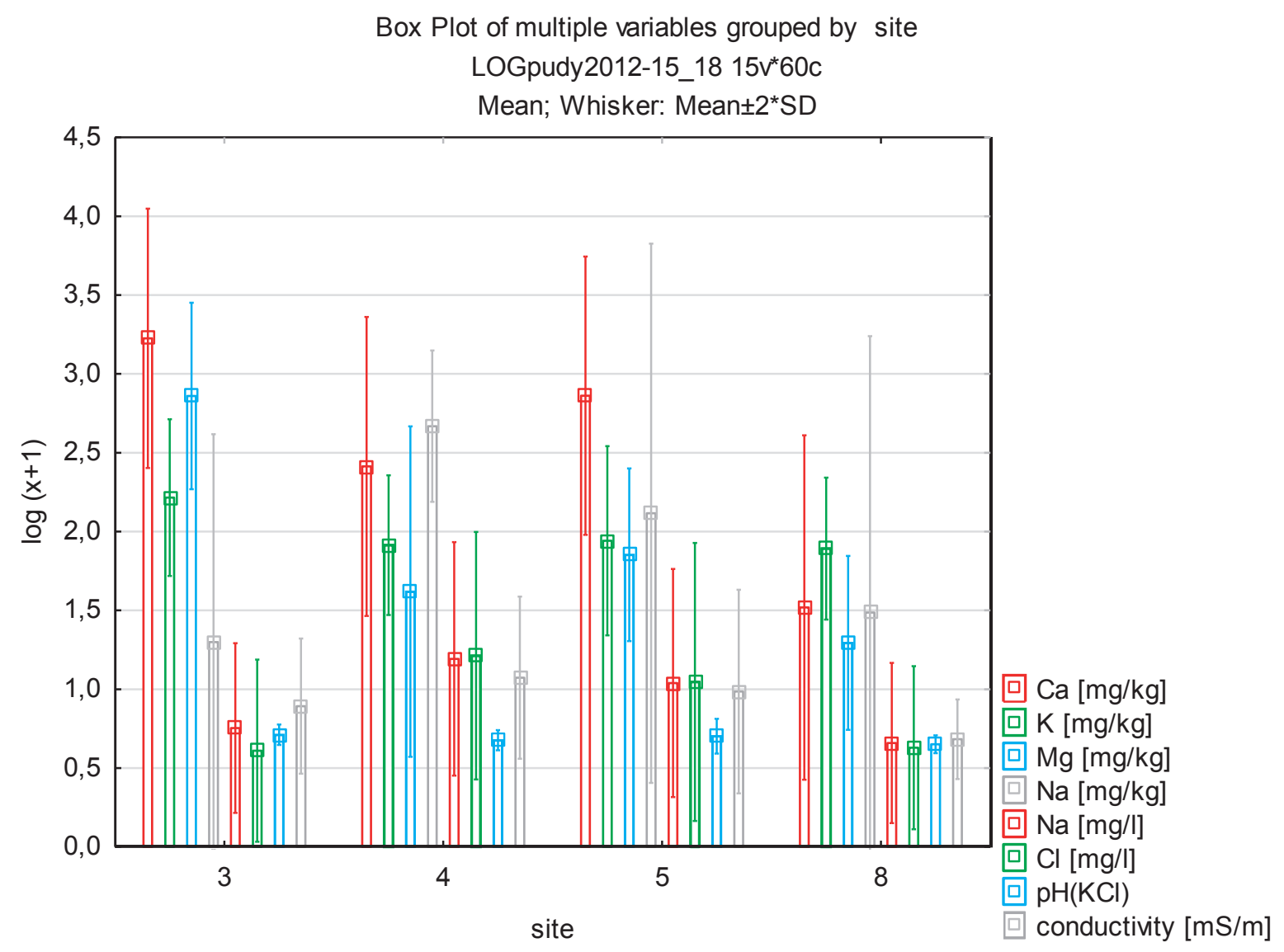

Fig. 1 Four study sites differed significantly in all the variables analysed, except $\mathrm{pH}_{\mathrm{H} 20}(\mathrm{ANOVA}, \mathrm{p}<0.05)$. Mean and standard deviation bars are shown. Variables in [mg/l] were analysed after water extraction and variables in [mg/kg] were analysed after Moehlich II extraction. 
There were no significant differences between samples from upper and lower soil horizons. Only slightly lower concentrations of all variables measured were recorded in samples from the low horizon. Distance of the samples from the road edge significantly affected the variables. The samples collected at a distance $10 \mathrm{~m}$ from the road edge had significantly higher conductivities and concentrations of $\mathrm{Na}^{+}, \mathrm{Cl}^{-}, \mathrm{Ca}^{2+}$ and $\mathrm{Mg}^{2+}$ ions than those collected at a distance $5 \mathrm{~m}$ from the road edge (ANOVA, $\mathrm{p}<0.05$ ).

There were trends in the concentration of the salt ions $\left(\mathrm{Na}^{+}, \mathrm{Cl}^{-}\right)$over time as the concentration of $\mathrm{Na}^{+}$ions detected after water extraction significantly increased during the study period 2012-2015-2018 (ANOVA, $\mathrm{p}<0.05$ ), while $\mathrm{Cl}^{-}$and $\mathrm{Na}^{+}$ions detected after Moehlich II extraction did not change significantly. At all sites, there were similar concentrations of these two ions detected after Moehlich II extraction during the study period, with a slight decrease in 2015 and increase in 2018 (Fig. 2). There was also a statistically significant effect of site $\times$ year interaction (ANOVA, $p<0.05$; Fig. 3 ). Concentrations of salt ions $\left(\mathrm{Na}^{+}, \mathrm{Cl}^{-}\right)$were highest in samples from sites \# 4 and 5, both close to the Grosse Ohe River, but there were no clear trends. Chloride ions $\left(\mathrm{Cl}^{-}\right)$ increased in samples from sites \# 4 and 5 and decreased in those from sites \# 3 and 8 between 2012 and 2018. Also concentrations of $\mathrm{Na}^{+}$ions, detected after both water and Moehlich extractions, increased in samples from sites \# 4 and \# 5 during the study period. Whilst the concentration of $\mathrm{Na}^{+}$ions continuously increased in samples from site \# 4 during the study period, the concentrations of $\mathrm{Na}^{+}$ions steeply increased from 2012 to 2015 and later slightly decreased in those from site \# 5 . However, concentrations of $\mathrm{Na}^{+}$ions in samples collected in 2018 are higher than in those collected in 2012.

There was a decrease in the concentrations of $\mathrm{Cl}^{-}$and $\mathrm{Na}^{+}$ions (Moehlich extraction) over time but after water extraction and the changes in concentrations of $\mathrm{Na}^{+}$ions were not obvious in the sample from site \# 8 .

The lowest concentrations of salt ions $\left(\mathrm{Na}^{+}, \mathrm{Cl}^{-}\right)$were recorded in samples from site \# 3 , where there were no trends but the largest variation in concentrations occurred during the study period.

\section{Conclusions and Recommendation}

In years 2012, 2015 and 2018, soil samples were collected in the eastern part of the Bavarian Forest NP and analysed in order to better understand the process of contamination of the national park ecosystems by deicing salt. We compared study sites and used Design of

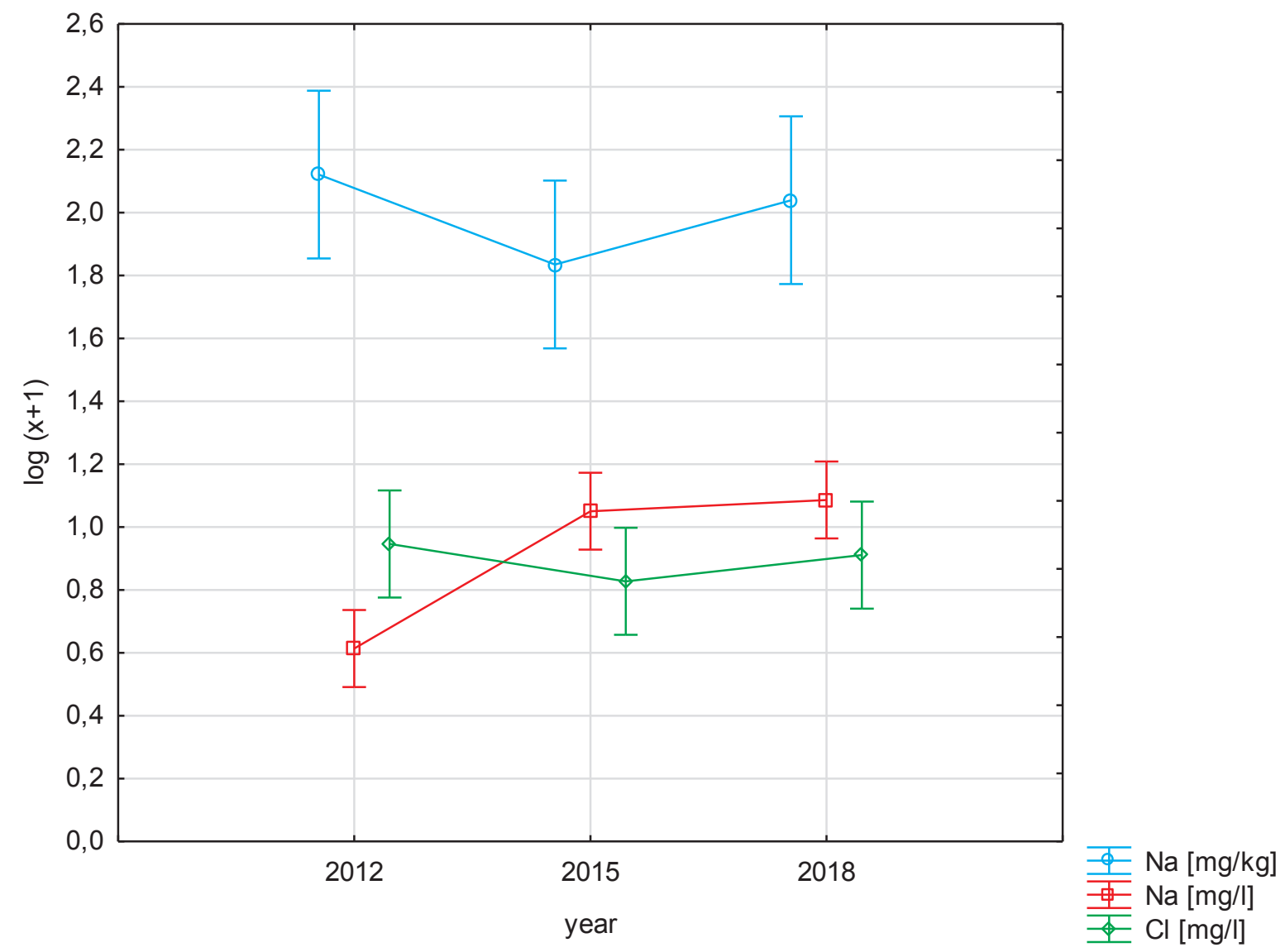

Fig. 2 Concentrations of salt ions $\left(\mathrm{Na}^{+}, \mathrm{Cl}^{-}\right)$recorded over time. Concentration of $\mathrm{Na}^{+}$ions detected after water extraction significantly increased during the study (ANOVA, $\mathrm{p}<0.05$ ). Vertical bars denote 0.95 confidence intervals. Variables in [mg/l] were analysed after water extraction and variables in $[\mathrm{mg} / \mathrm{kg}]$ after Moehlich II extraction. $\mathrm{Cl}^{-}$and $\mathrm{Na}^{+}$ions detected after Moehlich II extraction did not differ significantly. 
Repeated Measurement in Split-plot ANOVA to analyse changes in the concentrations of the salt ions $\left(\mathrm{Na}^{+}, \mathrm{Cl}^{-}\right)$ over time.

We found that the soil samples collected from the different sites differed significantly in their chemical parameters. The highest concentrations of $\mathrm{Na}^{+}$and $\mathrm{Cl}^{-}$ions were recorded in samples from sites \# 4 and 5, which are both located only several meters from the bank of the Grosse Ohe River, and water from the road is the main transport vector to the river of $\mathrm{Na}^{+}$and $\mathrm{Cl}^{-}$ions. Much higher concentrations of $\mathrm{Na}^{+}$and $\mathrm{Cl}^{-}$ions were recorded in samples collected 10 meters than 5 meters from the road edge. It is assumed that this because the location is subject to long-term contamination due to the accumulation of water there from melting snow. Site \# 3 is located along a local road to Racheldienesthütte, which is not treated with deicing salt. This study site is about 200 meters from the "Nationalparkstrasse" road and also located close to the Grosse Ohe River. This study site was originally established as a control for two nearby sites \# 4 and 5 , but differences in soil type and water regime limit the "control" role of site \# 3 .

Site \# 3 has anthropogenic soil with a higher proportion of cations $\left(\mathrm{Ca}^{2+}, \mathrm{Mg}^{2+}, \mathrm{K}^{+}\right)$and is at a greater distance from the Grosse Ohe River, which results in a lower flushing of soil sediments than at sites \# 4 and 5 . These differences may account for the high variability in the data recorded over the three years and no obvious trends in the concentrations of $\mathrm{Na}^{+}$and $\mathrm{Cl}^{-}$ions recorded in samples from site \# 3. Following this experience, we propose to keep site \# 3 as a "control" site, but only for monitoring vegetation, and establish a new "background" study site for monitoring soil chemistry. The new study site should be closer to the Grosse Ohe River, where the soil has similar characteristics and water regime, at least $200 \mathrm{~m}$ above the bridge on the "Nationalparkstrasse" road. Site \# 8 is located where the "Nationalparkstrasse" road passes through young dense forest. Aerosol, dust and snow ploughing are the main vectors of $\mathrm{Na}^{+}$and $\mathrm{Cl}^{-}$ions, while ground water is not so important at this site. Defoliation of trees close to the edge of the road and contamination of the soil will also probably increase in the future.

This research confirms that there has been an increase in the concentrations of $\mathrm{Na}^{+}$and $\mathrm{Cl}^{-}$ions in ecosystems in the Bavarian Forest NP as a result of applying deicing salt to roads. The highest concentrations, more than ten times higher than at a site where deicing salt was not applied, were recorded only several meters from the bank of the Grosse Ohe River. Amphibians, water insects and other extremely sensitive species and habitats occur in this part of the Bavarian Forest NP and are probably
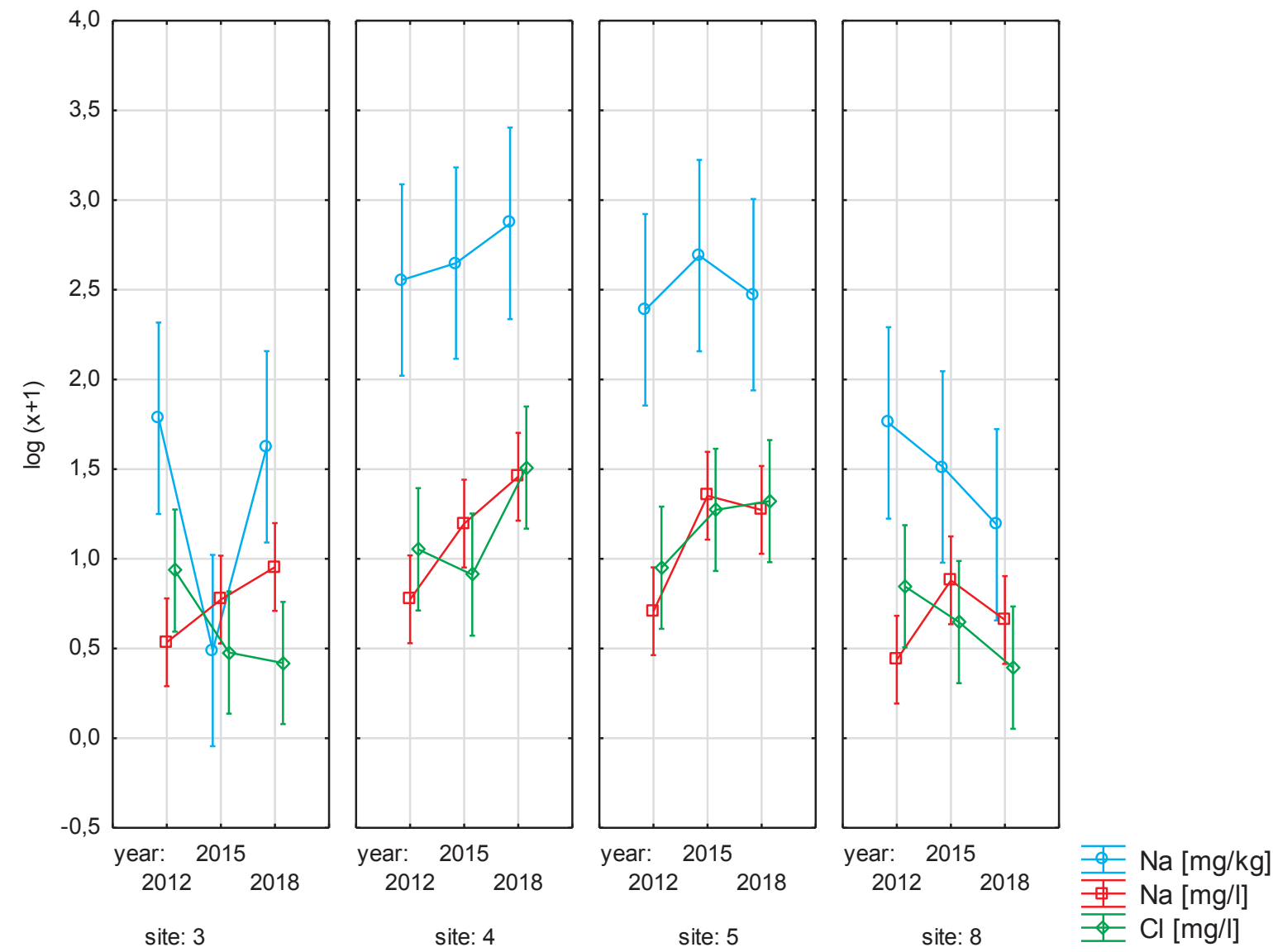

Fig. 3 Concentrations of the salt ions $\left(\mathrm{Na}^{+}, \mathrm{Cl}^{-}\right)$in samples from four study sites over time. There was a statistically significant effect of the site $\mathrm{x}$ year interaction (ANOVA, $\mathrm{p}<0.05$ ). Vertical bars denote 0.95 confidence intervals. Variables in [mg/l] were analysed after water extraction and variables in $[\mathrm{mg} / \mathrm{kg}]$ after Moehlich II extraction. $\mathrm{Cl}^{-}$and $\mathrm{Na}^{+}$ions detected after Moehlich II extraction did not differ significantly. 
adversely affected by the increasing salinity in their habitats. There is a need for more research focusing on a better understanding of effects of using deicing salt in this ecosystem together with using less damaging methods for maintaining the roads.

We established permanent monitoring sites along the "Nationalparkstrasse" road several decades after deicing salt was first used at this location. Therefore, we lack baseline data for soil variables. Due to the lack of this data it is difficult to distinguish the effects on the ecosystem and microhabitats of natural geochemical process from those caused by applying deicing salt and other human activities. For this more research on the soil characteristics is needed. Continuing the monitoring is necessary in order to better understand the geochemical process and effect of deicing salt on ecosystems in the Bavarian Forest NP. Also comparing our data with that obtained by monitoring at other locations will increase our knowledge, result in a better understanding of trends and result in the better protection of national park ecosystems.

\section{Acknowledgements}

We thank the following institutions and persons: LABTECH Brno s.r.o. - Laboratory Klatovy for chemi$\mathrm{cal}$ analyses and A. Dixon for revising the language. The Bavarian Forest NP Authority, the INTERREG Czech Republic-Bavaria project No. 368 (SILVA GABRETA monitoring of mountain ecosystems) and the Ministry of Education, Youth and Sports of CR within the National Sustainability Program I (NPU I), grant number LO1415 provided the financial support.

\section{REFERENCES}

Anonymous (2012) STATISTICA, v. 12, StatSoft, Inc, Tulsa, OK, USA; Available from: http://www.statsoft.com.

Amrhein C, Strong JE, Mosher PA (1992) Effect of deicing salts on metal and organic matter mobilization in roadside soils. Environ Sci Technol 26: 703-709.

Angold P G (1997) The impact of a road upon adjacent heathland vegetation: effects on plant species composition. J App Ecol 34: 409-417.

Bäckström M, Karlsson S, Bäckman L, Folkeson L, Lind B (2004) Mobilisation of heavy metals by deicing salts in a roadside environment. Water Res 38: 720-732.

Bässler C (2004) Das Klima im Nationalpark Bayerischer Wald Darstellung, Entwicklung und Auswirkung. Nationalparkverwaltung Bayerischer Wald.

Bässler C, Förster B, Moning Ch, Müller J (2009) The BIOKLIM Project: Biodiversity Research between Climate Change and Wilding in a temperate montane forest - The conceptual framework, Waldökologie, Landschaftsforschung und Naturschutz, Heft 7: 21-34.

Bryson GM, Barker AV (2002) Sodium accumulation in soils and plants along Massachusetts roadsides. Commun Soil Sci Plant Anal 33: 67-78.
Cunningham MA, Snyder E, Yonkin D, Ross M, Elsen T (2007) Accumulation of deicing salts in soils in an urban environment. Urban Ecosys 11: 17-31.

Czerniawska-Kusza I, Kusza G, Duzynski M (2004) Effect of deicing salts on urban soils and health status of roadside trees in the Opole region. Environ Toxicol 19: 296-301.

Denoel $\mathrm{M}$ et al (2010) Cumulative effects of road deicing salt on amphibian behavior. Aquat Toxicol 99: 275-280.

Elling W, Bauer E, Klemm G, Koch H (1987) Klima und Böden. Nationalparkverwaltung Bayerischer Wald.

eMaynadier PG, Hunter ML Jr. (1995) The relationship between forest management and amphibian ecology: a review of the North American literature. Environ Rev 3: 230-261.

Fennessey TW (1989) Guidelines for handling acid-producing materials on low volume roads. Transp Res Rec 1291: $186-189$.

Findlay SEG, Kelly VR (2011) Emerging indirect and long-term road salt effects on ecosystems. Ann NY Acad Sci 1223: 58-68.

Forman RTT, Alexander LE (1998) Roads and their major ecological effects. Annu Rev Ecol Syst 29: 207-231.

Gilson MP, Malivia JF, Chareneau RJ (1994) Highway runoff studied. Water Environ Technol 6: 37-38.

Godwin KS, Hafner MF, Buff (2003) Long-term trends in sodium and chloride in the Mohawk River, New York: the effect of fifty years of road-salt application. Environ Pollut 124: 273-281.

Hofstra G, Hall R (1971) Injury on roadside trees: leaf injury on pine and white cedar in relation to foliar levels of sodium chloride. Can J Bot 49: 613-622.

Karraker NE, James PG, James RV (2008) Impacts of road deicing salt on the demography of vernal pool-breeding amphibians. Ecol Appl 18: 724-734.

Křenová Z (2011) Effects of deicing salts in Bavarian Forest National Park, Part I and II. Project report. Ms. Depon in Bavarian Forest NP Authority.

Křenová Z, Chocholoušková Z, Zýval V (2012) Effects of applying deicing salt to roads in protected areas: a preliminary study in the Bavarian Forest National Park. Eur J Environ Sci 2: 56-61.

Mason CF, Norton SA, Fernandez IJ, Katz LE (1999) Deconstruction of the chemical effects of road salt on stream water chemistry. Environ Qual 28: 82-91.

National Research Council (1991) Highway Deicing: Comparing Salt and Calcium Magnesium Acetate. Spec. Rep. 235, Transp. Res. Board,Washington, DC.

Noack EM (1979) Witterung und Klima im Bayerischen Wald. Nationalparkverwaltung Bayerischer Wald.

Ostendorf DW, Pollack SJ, DeCheke ME (1993) Aerobic degradation of CMA in roadside soils: field simulations from soil microcosms. J Environ Qual 22: 299-304.

Richburg JA, Patterson WA, Lowenstein F (2001) Effects of road salt and Phragmites australis invasion on the vegetation of a Western Massachusetts calcareous lake-basin fen. Wetlands 21: 247-255.

Rusek J, Rusek J (1999) Impact of winter road salting on soil Collembola and other microarthropods. The conference report: Soil Zoology in Central Europe, České Budějovice.

Trombulack SC, Frissell CA (1999) Review of ecological effects of road on terrestrial and aquatic communities. Cons Biol 14: $18-30$.

van der Ree R, Smith DJ, Grilo C (2015) Handbook of the road ecology. Wiley Blackwell.

Wrobel M, Tomaszewicz T, Chudecka J (2006) Floristic diversity and spatial distribution of roadside halophytes along forest and field roads in Szczecin lowland (West Poland). Polish J Ecol 54: 303-309. 
Yousef YA, Wanielista MP, Harper HH (1985) Removal of highway contaminants by roadside swales. Transp Res Rec 1017: 62-68.

Zýval V, Křenová Z, Chocholoušková Z, Zýval V Jr., Zývalová J (2015) Effects of applying deicing salt to roads in protected areas of the Bohemian Forest region. Silva Gabreta 21: 43-52.
Zýval V, Křenová Z, Raus M, Štrupl V, Zýval V Jr., Zývalová J (2018) Effects of Deicing Salt in Protected Areas: Water Quality Monitoring in the River Basin with the Occurrence of a Rare Pearl Mussel. J Polish Mineral Eng Soc January-June: 99-102. 